\title{
Whither no-fault schemes in Australia: \\ Have we closed the care and compensation gap?
}

\section{Mark R Forwood}

School of Medical Science, Griffith University, Australia

\begin{abstract}
:
No-fault compensation in New Zealand, the Woodhouse report and statutory reforms to civil liability motivated consideration of no-fault schemes in Australia. In 2011, the Productivity Commission recommended adoption of a National Injury Insurance Scheme. Since 2016, the NDIS has developed nationally, followed by variations of the NIIS for motor vehicle and workplace accidents. Compensation for injuries outside the NIIS (eg medical negligence), or general damages or economic loss must be recovered through compulsory third-party claims or common law. For those cases, an attractive compromise between the common law and no-fault compensation exists in Menyawi's "public tort liability".
\end{abstract}

Corresponding author: Prof Mark R Forwood, School of Medical Science, Griffith University, Gold Coast Qld 4222, Australia

Email: m.forwood@griffith.edu.au

\section{Introduction}

Do 'No-Fault' schemes offer a viable alternative to common law actions in Australia? This question has arisen just a few times in the past 40 years. In the death throes of the Whitlam Government in the late 70 s, the Australian Woodhouse Report ${ }^{1}$ mirrored recommendations of its namesake in New Zealand just a few years earlier. The scheme for broad-based no-fault accident compensation was adopted in New Zealand in 1974. With anticipation, the Australian inquiry investigated the Government's desire "to set up a comprehensive and universal system of social insurance to cover incapacities arising from injury in terms both of rehabilitation and compensation". ${ }^{2}$ Unlike New Zealand, political events overtook the passage of the Bill drafted by the Whitlam Government, and it was eventually rejected in favour of the continuity of common law. As Kirby J subsequently expressed, one of the hurdles to such schemes, as faced by Whitlam's Bill, arises because "to deprive an individual of established civil rights would have to run the gauntlet of constitutional provisions and human rights requirements." 3 
The second major impetus arose as a result of the statutory limitations placed on the law of negligence following the "crisis in insurance" of 2002. For Australian legislators, the crisis apparently created a difficulty that "was beyond the judges", ${ }^{4}$ Therefore, several jurisdictions repossessed statutory control of liability through tort reform legislation, ${ }^{5}$ many preceding the unified approach to reform favoured by the Ipp Report. ${ }^{6}$ In many cases, civil liability acts have essentially restated elements of the common law. For example, Civil Liability Act 2003 (Qld) restates the common-law principle of causation that "the breach of duty was a necessary condition of the occurrence of the harm"7, and that the plaintiff bears the onus of proving, on the balance of probabilities, any facts relevant to causation. ${ }^{8}$ As noted by Dixon, such provisions act "as a 'reminder' to courts tempted to depart from the relevant principles". ${ }^{9}$ Although insurers perceived that the causes of the crisis were addressed, problems arose for plaintiffs in many of these statutory reforms because their access to common law was now denied, compensation was capped, ${ }^{10}$ and contributory negligence could be assessed at 100 per cent. ${ }^{11}$ By reiterating principles of common law, statutory schemes also fail to compensate "innocent victims of accident", as Wallis described them, because in the law of negligence, no damages are awarded in the absence of fault. ${ }^{12}$ This has been one of the underlying arguments for no-fault schemes.

In 2005, the decision of the High Court in Swain v Waverley Municipal Council ${ }^{13}$ provided a further catalyst for the NSW government to consider a no-fault scheme for victims of severe accidents. ${ }^{14}$ Carr's government was attracted to a no-fault accident scheme when the High Court reinstated an award of $\$ 3.75$ million in damages to Guy Swain, who was rendered quadriplegic after diving into a wave and hitting his head on a sandbar at Bondi beach. The question on Premier Carr's mind at the time was whether Mr Swain would have had access to compensation for catastrophic injuries if his accident had occurred after statutory changes in which the risk of injury was "inherent or obvious". ${ }^{15}$

These limitations and checks on compensation for catastrophic injury motivated many calls for a no-fault compensation scheme. ${ }^{16}$ In 2014, the Federal government and Council of Australian Governments returned their attention favourably to this question. ${ }^{17}$ Nonetheless, many critics of such schemes remain, notably the insurance industry and litigation lawyers. The latter argue principally that no-fault compensation schemes do not provide full compensation, whereas common law damages enable people to live independently. ${ }^{18}$ I will 
first examine the common elements of a no-fault compensation scheme, then address the validity some of the major criticisms directed at such schemes by organisations such as the Australian Lawyers Alliance (ALA), and finally suggest recommendations that might address some of the disadvantages of such a broad scheme.

\section{Negligence Law and No-Fault Schemes}

In common law, compensation is sought through the court in relation to the tort of negligence, which is based in establishing fault. Once a duty of care is established, the onus is on the plaintiff to prove that the duty was breached, and that the defendant was at fault. ${ }^{19}$ That is, the principle of causation as noted above. Such cases may take a considerable period of time to reach a judgment, before any compensation is awarded, if any. They may also be subject to appeal, extending the period before which compensation might restore the plaintiff to their position prior to the injury. Furthermore, in most States, the freedom of a plaintiff to pursue compensation for negligence may be limited by statutory provisions enacted after 2001, defining the limits of liability and capping awards of compensation. Moreover, as noted above, innocent victims of an accident in which fault cannot be ascribed, will not be compensated under common law. Nonetheless, statutory limitations notwithstanding, some plaintiffs may be compensated commensurable with the injury suffered. ${ }^{20}$

Conversely, no-fault schemes allow a plaintiff to seek compensation for an injury caused by an accident, without the onus of proving fault. ${ }^{21}$ No-fault schemes already exist in Australia, but are limited to workers compensation and motor vehicle accidents. In 2011, the Productivity Commission delivered their report on implementation of the National Disability Insurance Scheme (NDIS). ${ }^{22}$ The NDIS started in July 2013 as a trial in four locations. In July 2016, the NDIS finished its trial period and the full Scheme began rolling out across Australia. Though less reported, the Commission also proposed recommendations for a National Injury Insurance Scheme (NIIS), Australia's second major report on no-fault insurance since the Woodhouse Report. The Commission highlighted several advantages of broad-based systems of no-fault compensation. ${ }^{23}$ These included predictable care and support over a person's lifetime, consistent coverage of all injured people; and, faster compensation through a more efficient system. Another advantage is the reduced administrative costs, compared to common law actions. ${ }^{24}$ These advantages are attractive to an injured person, even though Wallis noted that one of the most significant disadvantages of no-fault systems is that 
victims tend to be under-compensated. ${ }^{25}$ Nonetheless, the Federal government committed to implementation of the NIIS, and in 2016 most States and Territories initiated the no-fault scheme for motor vehicle and workplace accidents, with some state-by-state differences among schemes. ${ }^{26}$

Unlike Australia, New Zealand has a broad based no-fault accident compensation system, which was originally provided for by the Accident Compensation Act 1972, which created the Accident Compensation Corporation to administer the scheme. ${ }^{27}$ Funding for the scheme is provided for different types of injury such as work-related, non-work-related, treatment (medical malpractice), and motor vehicle injury. The sources of funding for the scheme are drawn from employers, income tax, government and excise on petrol and vehicle registrations ${ }^{28}$. Although the scheme does not cover all types of psychiatric injury, the legislation did not limit common law claims for those injuries. As summarised by Field, it is a "scheme characterised by its swift compensation of the injured despite its bureaucratic administration". ${ }^{29}$ Nonetheless, despite the durability and putative success of the New Zealand Scheme, no-fault schemes are not universally welcomed.

\section{Critics of No-Fault Systems}

The Australian Lawyers Alliance (ALA) published a defence of common law remedies on their website, identifying four specific criticisms of no-fault schemes. ${ }^{30}$ First they state that "a victim's entitlement to compensation under the common law is calculated according to their loss: the compensation should be sufficient to restore them to the position in which they would have been, had the accident not occurred." ${ }_{1}$ Although it is acknowledged that no-fault schemes tend to under-compensate victims, ${ }^{32}$ it does not logically follow that all plaintiffs are fully compensated in common law. This is particularly the case since the statutory reforms from 2002 provided limits on compensation as noted above. In addition, to avoid the lengthy process of litigation, many plaintiffs may settle before a judgment is achieved, reducing costs but potentially diminishing the level of compensation that might be awarded. ${ }^{33}$

Second, the ALA argued that "common law deters people engaging in conduct that poses an unreasonable risk of injury to others." ${ }^{34}$ Like legislation, it is argued that the common law provides a means of deterrence for tortious behaviour. Wallis ${ }^{35}$ believes that this too is a specious argument in the present legislative environment. This is because deterrence is undermined by the application of liability insurance, insulating 
the tortfeasor from facing any burden related to their negligence. In addition, empirical evidence demonstrates that tort liability has an insignificant impact on preventing tortious behaviour. ${ }^{36}$ Third, the ALA notes that "the common law system of awarding compensation discharges a vital role in revealing latent risks to society", achieved through the forensic analysis of causal factors in negligence cases. This argument denies the fact that a proportion of negligence occurs through inadvertent negligence or inattention, and hence could not be avoided in the future through careful analysis of causes that might occur in common law. ${ }^{37}$ Finally, the ALA asserts that "no-fault and welfare-based schemes are inflexible, 'one size fits all', statutory systems that do not treat people according to their individual needs and circumstances." ${ }^{38}$ Again, many statutory provisions weaken this argument in common law by limiting compensation via caps, through contributory negligence, and by denying compensation to those who cannot establish fault. In particular, the Victorian Government eliminated plaintiff's rights to seek compensation for minor claims by requiring that compensation only be valid for significant injury ${ }^{39}$ (being more than five per cent bodily impairment). Such statutory limitation certainly meets the ALA's definition of one-size-fits-all.

Naturally, the second group of stakeholders to criticise no-fault schemes are the insurance companies. The rise in insurance premiums, annual losses prior to 2001 and the collapse of the large insurance company HIH were proposed as the cause of the insurance crisis. However, subsequent analysis revealed that the reduction in availability of insurance was largely due to "cyclical factors affecting the insurance market exacerbated by one-off events, and not due to excessive litigation or compensation payouts." ${ }^{40}$ In addition, the collapse of HIH did not occur because of excessive payouts. Rather, the collapse resulted from internal failures in the company and ineffective corporate governance. ${ }^{41}$ The so-called crisis was not, therefore, a crisis of public liability per se, but it did, nonetheless, engender reform of the system. Field points out that following the statutory reforms of 2002, insurance industry profits steadily rose over the next few years in to the billions, ${ }^{42}$ and so the companies saw those reforms as being very successful. By preventing plaintiffs from initiating claims that would draw on those profits, there was clearly no appetite to support no-fault schemes when the statutory reforms had delivered significant growth and profitability.

\section{Do 'No-Fault' schemes offer a viable alternative?}


No-fault schemes are no panacea to replace common law. The scheme in New Zealand endures, but has been subject to many amendments, and disadvantages remain. These systems compensate victims relatively quickly but tend to undercompensate them; though the latter criticism is less significant since the introduction of statutory reforms to liability. No-fault systems are also poor at providing deterrence to tortious behaviour. Wallis observes that motor vehicle accident fatalities in the Northern Territory and New Zealand rose from 16-20 per cent after these jurisdictions introduced no-fault schemes. ${ }^{43}$ Is there a way forward that might capitalise on the advantages that each system offers, while reducing their negative characteristics?

A proposal has been developed to combine the two systems in a compromise approach termed "public tort liability". ${ }^{44}$ Menyawi proposed that the State create a compensation scheme for victims so that they are independently compensated for personal injury regardless of the cause. ${ }^{45}$ This allows an injured person to benefit from the advantages of no-fault compensation. The unique feature of the proposal is that the State also pursues the tortfeasor, independently, to assess if the victim's injury would not have occurred but for the negligence of the defendant. After having assessed whether the defendant was at fault, and the extent of the damages, those damages are remitted by the defendant to the State. ${ }^{46}$ These damages in turn fund the operation of the scheme. ${ }^{47}$

Menyawi argues that because the State receives damages from a defendant, this approach can offset the under-compensation characterised by pure no-fault schemes. Compensation also remains relatively fast, and the time taken to assess the breach of duty of the defendant does not disadvantage the plaintiff. Conversely, this scheme has the possibility of restoring the element of deterrence because the State pursues the defendant, requiring them to take responsibility for the harm caused. ${ }^{48}$ As Wallis notes "the almost criminallike aspect of being pursued by the State is more certain than being pursued by an individual in tort, and would arguably lend weight to increased deterrence". ${ }^{49}$ It could be argued that the insurance industry still moderates the extent of that deterrence. This is because the State would only pursue adequately insured defendants, meaning again that insurers would stand in the shoes of the defendant. Wallis asserts, however, that the act of pursuing the defendant at all satisfies principles of ethical justice. That is, the pursuit of damages allows victims to seek meaning and a sense of self justice because defendants are held accountable 
for their wrongs. ${ }^{50}$ At face value, public tort liability looks like an attractive proposition, so how might such a scheme work in the present environment?

Regardless of the utility argued for public tort liability, implementation relies on political factors. It is difficult in any political environment to achieve statutory innovation. Whitlam's endeavours to implement the recommendations of the Woodhouse inquiry, for example, were overwhelmed by the political crisis of 1975. The contemporary political environment is no less challenging. Implementation of public tort liability would require extensive procedural change, with significant cost implications. In addition, the NIIS has national consensus but has not rolled-out as a national scheme. Rather, it is implemented in each State in which it is adopted. Achieving national uniformity, therefore, is a major hurdle. Moreover, the NIIS is largely limited to motor vehicle accidents or workers' compensation, though it may extend in time to medical accidents and public liability.

When Menyawi proposed the concept, the NIIS did not exist, and a mechanism to realise his concept was not proposed. In the present environment, the NIIS arguably provides an efficient vehicle through which public tort liability might be implemented. This would reduce the administrative and financial burden of developing new agencies and structures to manage the scheme. Like its counterpart, the NDIS, an operational goal of the NIIS is that it must be managed in a way that ensures its operation is financially sustainable. ${ }^{51}$ It is currently funded by levies on motorists. With public tort liability, defendants would pay damages to the State, an additional source of revenue to support the scheme, contributing to financial sustainability.

Similar to other statutory bodies such as the Australian Securities and Investments Commission (ASIC), or the Australian Taxation Office (ATO), the NIIS could be granted investigative powers to pursue defendants. One branch of the NIIS would continue to administer no-fault schemes for motor vehicle accidents or workers' compensation, and another branch would investigate accidents to assess if the victim's injury occurred as a result of the negligence of a defendant. Menyawi identifies that a limitation of the approach is potential dissatisfaction with the outcome from defendants, ${ }^{52}$ arguing the scope of their liability, or plaintiffs, arguing the level of compensation. Applying administrative law mechanisms to assess the merits of a case, disagreements of those sorts could be assessed through internal review, the Administrative Appeals Tribunal, 
or the legality of the decision tested through judicial review. Those mechanisms contribute, therefore, to a body of case law providing some supervision of the State's actions and decisions. ${ }^{53}$

\section{Conclusions}

In 2000, Kirby J lamented "the continuing rise of the imperial tort of negligence ... which has expanded beyond all recognition from the days of Donoghue $v$ Stephenson." ${ }^{54}$ That rise was a feature of the insurance crisis, but its expansion has been restricted by statutory reforms. The adoption of no-fault compensation in New Zealand, the statutory reforms limiting compensation for negligence, and consequent limits on restorative justice for plaintiffs, motivated calls to introduce no-fault compensation schemes. In addition to the NDIS, the Productivity Commission report in 2011 recommended adoption of a National Injury Insurance Scheme; ${ }^{55}$ a call that was heard by the Federal government. Since 2016, the NDIS has developed in States and Territories to support significant and permanent disability, with variations of the NIIS for motor vehicle and workplace accidents. The focus of those schemes is on care, rather than compensation. Australia has not gone as far as the broad-based 'no-fault' scheme adopted in New Zealand. Accordingly, compensation for injuries resulting from accidents outside the scope of the NIIS (eg medical negligence), general damages (e.g. pain and suffering) or economic loss must still be recovered through compulsory thirdparty claims or the common law. Therefore, the gap between care and compensation has not closed, but it has narrowed.

No-Fault schemes have several advantages in their ability to compensate victims of injury where no fault can be established. For example, they provide relatively prompt compensation and predictable care and support over the life of the plaintiff. In contrast, they have little deterrent value and commonly under-compensate victims, a disadvantage less evident in the shadow of statutory liability reform. For claims outside the scope of the NIIS, an attractive marriage between the common law and no-fault compensation can be found in "public tort liability", ${ }^{56}$ in which the State compensates victims and then seeks redress from defendants for whom negligence has been established. Such a scheme allows for prompt compensation to victims, it provides a deterrent value to tortfeasors and reimburses the fund from which the government pays compensation. Kirby J believes that unless empirical data, rather than rhetoric, makes a compelling case for change in compensation "in most parts of the world, negligence will continue its imperial expansion. As with 
other imperial forces in the past, there will be beneficiaries. And there will be victims." ${ }^{57}$ The concept of public tort liability makes a compelling case to establish an armistice between these imperial forces and is deserving of legislative scrutiny where cases fall outside the scope of the NDIS or current NIIS guidelines, and where general damages and compensation for economic loss are sought. I have proposed that the NIIS offers an opportunity to implement public tort liability, integrating no-fault compensation with tort liability.

Mark R Forwood is the Foundation Chair of Anatomy, and Head of the School of Medical Science, at Griffith University.

\section{References}

${ }^{1}$ Arthur Woodhouse and Charles Meares, Compensation and Rehabilitation in Australia: Report of the National Committee of Inquiry (Commonwealth of Australia, July 1974).

${ }^{2}$ Ibid 274.

${ }^{3}$ Justice Michael Kirby, ‘An International Perspective on Tort System Reforms. Tort System Reforms: Causes, Options, Outcomes' (speech delivered at PIAA International Workshop, The Royal College of Physicians, London, England, 11 September 2000).

${ }^{4}$ Andrew Field, “"There Must Be A Better Way": Personal Injuries Compensation Since the "Crisis in Insurance" (2008) 13(1) Deakin Law Review 68 [3].

${ }^{5}$ Civil Liability Act 2002 (NSW); Civil Liability Act 2003 (Qld); Civil Liability Act 2002 (Tas); Wrongs and Limitations of Actions Acts (Insurance Reform) Act 2002 (Vic); Civil Liability Act 2002 (WA); Civil Law (Wrongs) Act 2002 (ACT).

${ }^{6}$ David Ipp et al, Review of the Law of Negligence: Final Report (Commonwealth of Australia, September 2002) $35[1]$.

${ }^{7}$ Civil Liability Act 2003 (Qld) s 11(1).

${ }^{8}$ Ibid s 12

${ }^{9}$ Nicolee Dixon, 'Reform of Negligence Law - The Queensland Response: The Draft Civil Liability Bill 2002' (Research Brief No 2003/01, Queensland Parliamentary Library, 2003) 12 [2].

${ }^{10}$ Wrongs Act 1958 (Vic) s 28G; Civil Liability Act 2002(NSW) s 16(2).

${ }^{11}$ Civil Liability Act 2003 (Qld) ss 24. 
${ }^{12}$ Eleanor Wallis, 'Justice, Janus-Like: The Future of Australian Personal Injury Compensation' (2015) 7

The ANU Undergraduate Research Journal 120 [4].

${ }^{13}$ Swain v Waverley Municipal Council [2005] HCA 4 (9 February 2005).

${ }^{14}$ Talina Drabsch, ‘No Fault Compensation' (NSW Parliamentary Library Briefing Paper No 6/05, May 2005) 1.

${ }^{15}$ Ibid $2[4]$.

${ }^{16}$ Field, above n 4; Wallis, above n 11; David Weisbrot and Kerry J Breen, 'A No-Fault Compensation System for Medical Injury is Long Overdue' (2012) 197 Medical Journal of Australia 296-298.

${ }^{17}$ PricewaterhouseCoopers Australia, "National Injury Insurance Scheme: Motor Vehicle Accidents.

Decision Regulation Impact Statement" (June 2014) http://ris.pmc.gov.au/2017/06/22/national-injuryinsurance-scheme-motor-vehicle-accidents.

${ }^{18}$ Wallis, above n 11, $3[1]$.

${ }^{19}$ Danuta Mendelson, The New Law of Torts (Oxford University Press, 2008) 321.

${ }^{20}$ Australian Lawyers Alliance (ALA), The Importance of Common Law

https://www.lawyersalliance.com.au/about-us/the-importance-of-common-law [6].

${ }^{21}$ Wallis, above $\mathrm{n} 11,118$.

${ }^{22}$ Productivity Commission, Disability Care and Support (Report No 54 2011, Commonwealth of Australia) 43.

${ }^{23}$ Ibid 43.

${ }^{24}$ Wallis, above $\mathrm{n} 11,122$.

${ }^{25}$ Ibid 122 [4].

${ }^{26}$ Department of Prime Minister and Cabinet, National Injury Insurance Scheme: Motor Vehicle Accidents

(22 June 2017) http://ris.pmc.gov.au/2017/06/22/national-injury-insurance-scheme-motor-vehicle-accidents.

${ }^{27}$ Rumpelstatskin, in 'Australian Economy', Why Not Adopt NZ's No-Fault National Insurance (19 January 2012) Macrobusiness website https://www.macrobusiness.com.au/2012/01/why-not-adopt-nz\%E2\%80\%99sno-fault-national-insurance/.

${ }^{28}$ Field, above n 4, 87.

${ }^{29}$ Ibid 89 [2]. 
${ }^{30}$ Australian Lawyers Alliance, above n 19.

${ }^{31}$ Ibid.

${ }^{32}$ Drabsch, above n 13; Weisbrot and Breen, above n 15, 297.

${ }^{33}$ Wallis, above $\mathrm{n} 11,121$.

${ }^{34}$ Australian Lawyers Alliance, above n 19.

${ }^{35}$ Wallis, above $\mathrm{n} 11,123$.

${ }^{36}$ W Jonathan Cardi, Randall D Penfield and Albert H Yoon, 'Does Tort Law Deter Individuals? A

Behavioral Science Study' (2012) 9(3) Journal of Empirical Legal Studies 567-603.

${ }^{37}$ Wallis, above $\mathrm{n} 11,124$.

${ }^{38}$ Australian Lawyers Alliance, above n 19.

${ }^{39}$ Wrongs Act 1958 (Vic) s 28LE.

${ }^{40}$ Wallis, above $\mathrm{n} 11,6$.

${ }^{41}$ Field, above n 4, 76 .

${ }^{42}$ Ibid 83 [3].

${ }^{43}$ Wallis, above $\mathrm{n} 11,124$.

${ }^{44}$ Hassan El Menyawi, 'Public Tort Liability: An Alternative to Tort Liability and No-fault Compensation' (2002) 9(4) Murdoch University Electronic Journal of Law.

${ }^{45}$ Ibid [73].

${ }^{46}$ Ibid [74].

${ }^{47}$ Ibid [77].

${ }^{48}$ Wallis, above $\mathrm{n} 11,125$.

${ }^{49}$ Ibid 126

${ }^{50}$ Wallis, above $\mathrm{n} 11,126[2]$.

${ }^{51}$ National Injury Insurance Agency Queensland, Necessary and Reasonable Decision Making https://niis.qld.gov.au/forms-policy-resources/guidelines/.

${ }^{52}$ Menyawi, above n 43 [87].

${ }^{53}$ Ibid [88]

${ }^{54}$ Kirby, above $\mathrm{n} 3,4$ of 11 .

${ }^{55}$ Productivity Commission, above n 21, 43. 
${ }^{56}$ Menyawi, above $\mathrm{n} 43$.

${ }^{57}$ Kirby, above n 3, 8 of 11. 